\title{
LIVING VALUE EDUCATION BAGI ANAK BERBASIS AL-QUR'AN
}

\author{
Musyfiq Amrullah \\ Institut PTIQ Jakarta \\ Email: abi.musyfiq@gmail.com
}

\begin{abstract}
The conclusion of this dissertation is that Living Value Education for children is based on The Quran, namely the education of the values of life in the form of religious, nationalist, integrity, independence, tolerance, and mutual cooperation which are the actualization of the maqâshid al-Qur'an. namely personal benefit common benefit and benefit to build a community. These values must be taught to become personalities to students which are based on the child's psychological development, namely at the basic level, because in this level they have a high enough egocentricity and tend not to have the will to see many things from the perspective of others. This LVE is integrated through the intracurricular, cocurricular and extracurricular learning processes in educational institutions. The concept of LVE in the al-Qur'an for children is to make value education with the principle of not burdening giving light burdens (and instilling responsibility with the principle of gradual/gradual. Living Value Education for children is found as life value education that starts from the time the child is in the womb to the age of puberty. This is based on the terms of the Quran related to children, namely: 1. Walad shows the child who is born, whether there is a nasab connection or not and the term walad does not limit whether they are still small or already large; 2. Ibn (which means boy or bint is a girl. This term is taken from the root word banau (the plural form is abnâl). The mention in Arabic, it is possible that a child is a building for their parents. Parents as figures to build it. Allah made the parents as the builders of the building to create independent offspring; 3. Tifl a newborn child, the word thiflu means a child who still needs guidance and nurture; 4. Gulam shows a child who is entering puberty. From these four terms, it can be concluded that children from birth to puberty need education and build them so that they are stable and independent. So the basic education degree is the right level to strengthen the basics of Living Value Education. This writing supports the opinion of alGhazâly and Abdullah Nâsih 'Ulwan about education starting from womb, Thomas Lickona about the necessity to instill moral values and character that can be taught in schools, even schools have the authority to train values, morals and character. This dissertation also supports the opinion of David Hume, about values that oppose the concept of Decrates' Rationality, which justifies values and morality based on reason alone. This dissertation also supports the opinion of Darwis Hude and Doni Koesoema about human potential which is not limited to intelligence, but there are several other intelligences that need to be developed in a balanced manner and evaluation of assessments is not only focused on cognitive ones.
\end{abstract}


This dissertation also supports the opinions of Ibn Kathir, Muhamad Qutbh, Nasaruddin Umar, and Nur Arfiyah Febriani about gender, namely that a mother is allowed to have activities outside the home with several conditions. On the other hand, this dissertation is different from Thomas Aquinas' concept of value, which considers good and bad values not by his will but only tools of God's behavior, the concept of values and the concept of Living Value Education (LVE) Diana Tillman, Rani Anggraini Dewi, and ALIVE (Association For Living Value Education) International. They only limit Living Value Education to twelve values, namely: peace, appreciation, love, responsibility, happiness, cooperation, honesty, humility, tolerance, simplicity, freedom, and unity. This dissertation is also different from Thomas Lickona's opinion which limits moral values with respect and responsibility. This dissertation is also different from the opinion of al-Qurthuby and As-Suyuthy who refuse women to engage in public activities.

The method used by the author in this study used a qualitative method, based on library research (library research) using a transcendental phenomonology approach. Meanwhile, the method of interpretation used is the thematic method (tafsir maudhu'i) both when analyzing problems and when using the verses of the Qur'an.

Keywords : living value education. child, al-'qur'an 
Abstrak: Penelitian ini adalah, bahwa Living Value Education bagi anak berbasis al-Qur'an yaitu pendidikan nilai-nilai kehidupan berupa nilai- nilai religius, nasionalis, integritas, kemandirian, toleransi, dan gotong royong yang merupakan aktualisasi dari maqâshid alQur'an yaitu kemaslahatan pribadi kemaslahatan bersama dankemaslahatan membangun komunitas. Nilai-nilai ini harusdiajarkan menjadi kepribadian kepada anak didik yang dilandaskan pada perkembangan psikologis anak yaitu pada jenjang dasar, karena dalam jenjang ini mereka memiliki egosentris yang cukup tinggi dan cenderung tidak memiliki kemauan untuk melihat banyak hal dari sudut pandang orang lain. LVE ini diintegrasikan melalui proses pembelajaran intrakurikuler, kokurikuler, dan ekstrakurikuler di lembaga pendidikan. Konsep LVE dalam al-Qur'an bagi anak adalah dengan dijadikannya pendidikan nilai dengan prinsip tidak memberatkan memberikan beban yang ringanl dan menanamkan tanggung jawab dengan prinsip gradual/bertahap( Living Value Education bagi anak ditemukan sebagai pendidikan nilai kehidupan yang diawali sejak anak dalam kandungan hingga usia akil baligh. Hal ini berdasarkan term al-Quran terkait anak, yaitu: 1. Walad menunjukan anak yang dilahirkan, baik adanya hubungan nasab ataupun tidak dan term walad tidak membatasi masih kecil ataupun sudah besar; 2. Ibn yang artinya anak laki-laki atau bint $t^{\mathrm{J}}$ ) anak perempuan. Term ini terambil dari akar kata banau bentuk pluralnya adalah abnâ Penyebutan tersebut dalam bahasa Arab dimungkinkan adanya anak merupakan bangunan bagi orang tuanya. Orang tua sebagai sosok untuk membangunnya. Allah menjadikan orang tua sebagai pendiri bangunan untuk mewujudkan terlahirnya keturunan yang mandiri; 3 . Tifl anak kecil yang baru dilahirkan, kata thiflu berarti anak kecil yang masih memerlukan bimbingan dan asuhan; 4. gulam menunjukan anak yang memasuki usia akil baligh. Dari keempat term ini disimpulkan bahwa anak sejak kelahirannya hingga akil baligh membutuhkan pendidikan dan membangunnya agar mapan dan mandiri. Maka Strata pendidikan dasar merupakan jenjang yang tepat untuk memperkuat dasar-dasar Living Value Education. tulisan ini mendukung pendapat al-Ghazâly dan Abdullah Nâsih'Ulwan tentang pendidikan dimulai sejak usia kandungan, Thomas Lickona tentang keharusan menanamkan nilai-nilai moral dan karakter dapat diajarakan di sekolah, bahkan sekolah mempunyai otoritas untuk melatih nilai-nilai, moral dan karakter. Penelitian ini juga mendukung pendapat David Hume, tentang nilai yang menentang konsep Rasionalitas Decrates, yang membenarkan nilai dan moralitas berdasarkan akal belaka. Penelitian ini juga mendukung pendapat Darwis Hude dan Doni Koesoema tentang potensi manusia tidak terbatas kecerdasan akal, tapi ada beberapa kecerdasan lain yang perlu dikembangkan secara seimbang dan evaluasi penilaian tidak hanya dititik beratkan kepada yang bersifat kognitif. Penelitian ini juga mendukung pendapat Ibnu katsir, Muhamad Qutbh, Nasaruddin Umar, dan Nur Arfiyah Febriani tentang gender yaitu bolehnya seorang ibu beraktifitas diluar rumah dengan 
beberapa syarat.

Di sisi lain penelitian ini berbeda dengan konsep nilai Thomas Aquinas yang menganggap nilai baik dan buruk bukan atas kehendak dirinya tapi hanya alat dari perilaku Tuhan, konsep nilai dan konsep Living Value Education (LVE) Diana Tillman, Rani Anggraini Dewi, dan ALIVE (Association For Living Value Education) International. Mereka hanya membatasi Living Value Education dalam duabelas nilai saja yaitu: kedamaian, penghargaan, cinta, tanggung jawab, kebahagiaan, kerjasama, kejujuran, kerendahan hati, toleransi, kesederhanaan, kebebasan, dan persatuan. Penelitian ini juga berbeda dengan pendapat Thomas Lickona yang membatasi nilai moral dengan hormat dan tanggung jawab. Penelitian ini juga berbeda dengan pendapat al-Qurthuby, dan As-Suyuthy yang menolak perempuan untuk beraktifitas di ruang publik.

Metode yang digunakan oleh penulis dalam penelitian ini menggunakan metode kualitatif, berbasis riset kepustakaan (library research) dengan menggunakan pendekatan fenomonologi transendental. Sedangkan metode penafsiran yang digunakan adalah metode tematik (tafsir maudhu'i) baik saat menganalisa permasalahan maupun ketika menggunakan ayat-ayat al-Qur'an.

Kata Kunci : living value education , anak, al-'qur'an 


\section{PENDAHULUAN}

Permasalahan pendidikan menarik untuk dikaji lebih mendalam. Kasuskasus yang terkait dengan degradasi moral semakin bertambah. Pendidikan tetap memiliki nilai positif, walaupun kasus yang melibatkan anak cukup banyak. Pendidikan tetap mengalami kemajuan. Indikator kemajuan dapat dilihat dari kemampuan kuantitatif baca tulis. Kemampuan masyarakat usia sekolah mencapai 67, 24 \%. Kemajuan ini dimungkinkan karena adanya Inpres Sekolah Dasar yang telah mencapai hampir seluruh wilayah Indonesia. Di sisi kualitatif, pendidikan dianggap gagal karena dianggap belum berhasil membangun karakter bangsa. Pembentukan karakter sudah lama menjadi pembahasan di Indonesia. Karakter dianggap oleh para ahli dan tokoh sebagai salah satu alternatif yang dapat menjadi solusi masalah krisis akhlak yang terjadi di negeri tercinta.

Penyimpangan perilaku peserta didik pada zaman akhir ini banyak dilakukan oleh peserta didik yang tidak lagi mencerminkan layaknya seorang pelajar. Di antara perilaku yang menunjukkan krisis akhlak pada siswa adalah kebiasaan saling bermusuhan, seperti tawuran antarsekolah, saling lempar batu bahkan juga saling bunuh,. Seolah nyawa t idak ada harganya bagi mereka. Thomas Lickona, seorang pendidik karakter dari Cortland University dikenal sebagai Bapak Pendidikan Karakter Amerika. Licona dalam Kosim, mengungkapkan bahwa sebuah bangsa sedang menuju kehancuran jika sudah tampak adanya sepuluh tanda-tanda zaman. Pendapat Lickona ini dikutip oleh Mohammad Kosim dalam makalahnya "Urgensi pendidikan karakter". Sepuluh tanda-tanda Zaman itu adalah meningkatnya kekerasan di kalangan remaja, membudayanya ketidakjujuran, fanatisme kelompok, rendahnya rasa hormat kepada orangtua dan guru, semakin tidak jelasnya prilaku baik dan buruk, bertutur bahasa yang tidak santun, meningkatnya perilaku merusak diri (narkoba, minuman keras, seks bebas), rendahnya rasa tanggung jawab baik sebagai individu atau sebagai warga Negara.

Tidak dipungkiri, arus globalisasi dalam berbagai aspek berpengaruh terhadap Indonesia. Generiasi muda menjadi tonggak kemajuan tersebut. Di samping itu, generasi yang akan mengembangkan negeri ini kelak. Oleh karena itu, arus globalisasi berpengaruh terhadap perilaku generasi muda Indonesia, baik pengaruh yang bersifat positif dan negatif. Hingga saat ini masyarakat dan pemerintah membentengi pengaruh negatif terus. Upaya itu semakin ditingkatkan agar generasi muda terlindungi dari pengarauh-pengaruh negatif. Bahkan, Pendiri negara ini memimpikan terwujudnya negeri yang adil dan makmur dimana penduduknya beriman dan bertaqwa kepada Allah Yang Maha Esa, sejahtera, berakhlak yang luhur dan mulia, berkecukupan, dan tidak berada dalam kekurangan, penuh kemandirian dan memiliki kemampuan dalam persaingan global sehingga terjaga eksistensi bangsa yang relijius dan penuh integritas. Namun pengaruh-pengaruh negatif nampaknya tidak dapat terbendung. Akibatnya, permasalahan moralitas generasi muda merambah bukan hanya di kota-kota besar tapi juga sudah masuk ke desa-desa dan perkampungan.

Pengaruh negative dari dampak globalisasi tidak dapat dilihat langsung. Pengaruh ini ditandai dengan penurunan moral generasi muda. Selain itu, terdapat beberapa tanda merosotnya moral generasi.

Pertama, tawuran antarsekolah dan antarwarga yang diawali dengan permasalahan yang kecil. Permasalahan ini mendorong mereka saling menyakiti, melukai bahkan membunuh. Tawuran antaranak sekolah menjadi trend. Mereka 
melakukan tawuran dengan membawa senjata. Perkelahian massal atau yang biasa disebut tawuran, sering terjadi di antara pelajar, bahkan bukan hanya antarpelajar SMP dan SMU, tapi juga sudah merambah ke dunia kampus. Di antaranya pada kampus yang terdapat di kota-kota besar seperti Jakarta, Surabaya, Medan, Makassar dan lain sebagainya.

Kedua, Penyalahgunaan narkoba oleh beberapa oknum pejabat dan stakeholder pendidikan. Penanganan korban penyalahgunaan narkoba di Indonesia merupakan hal yang sangat penting. Narkoba memiliki zat adiktif yang dianggap sangat membahayakan diri maupun orang lain.

Hal ini disebabkan oleh karena permasalahan narkoba ini sangat komplek. Maraknya penggunaan narkoba dari waktu ke waktu dengan berbagai macam modus banyak didapatkan. Kasus-kasus kejahatan ini polanya sangat beragam dan jaringannya juga sangat massif. Hal yang sangat dikhawatirkan pada kasus narkoba ini adalah penyebarannya yang menyeluruh. Penyebaran narkoba menembus kalangan anak-anak pelajar (seusia TK dan SD). Mereka menginsumsi narkoba diperkirakan tidak mengetahui apa-apa yang dia konsumsi (makanan atau minuman). Padahal disana adanya kelompok masayarakat yang telah mengoplos makanan atau minumannya dengan narkoba.

Para pengguna narkoba di Indonesia pada tahun 2017 mengalami kenaikan. Menurut Badan Narkotika Nasional (BNN) mencapai 5,1 juta orang. Jumlah ini menempatkan Indonesia menjadi negara pengguna narkoba terbesar di Asia. Dari jumlah tersebut terdapat $40 \%$ penggunanya berasal dari kalangan pelajar dan mahasiswa, diantara mereka berawal dari penasaran kemudian mencoba, ketagihan, ada pula yang kecanduan sehingga menjadi bandar narkoba. Hal itu disampaikan oleh Sulistiandriatmoko, Kepala Bagaian Humas BNN pada diskusi bertema "stop Narkoba" pada, 14 November 2017.

Sementara pada tahun 2018, terdapat berita mencengangkan terkait narkoba. Kepala Badan Narkotika Nasional (BNN), Heru Winarko mengklaim bahwa pengguna Narkoba mayoritas adalah generasi muda atau para pelajar. Hal itu diungkapkan dalam press release tahun $2018 .{ }^{10}$ Banyaknya generasi muda yang terjebak dalam narkoba memerlukan perhatian serius dari semua pihak. Anak muda merupakan kelompok masyarakat yang akan memegang peran kepemimpinan pada masanya. Oleh karena itu, merusak generasi muda adalah ancaman serius bangsa dan negara.

Menurut catatan Komisi Perlindungan Anak Indonesia (KPAI), sebanyak 2,9 juta anak menjadi pecandu narkoba karena terpengaruh dari orang terdekat. Hal itu disampaikan Komisioner bidang kesehatan KPAI, Siti Hikmawatty. KPAI menyebutkan bahwa penanganan dilakukan terhadap 2,218 kasus terkait masalah kesehatan dan napza yang menimpa anak-anak. Sebanyak 15, 69 persen diantaranya pecandu narkoba sementara 8.1 persen kasus sebagai pengedar narkoba. Jumlah yang demikian merupakan jumlah yang cukup banyak. Karena, jumlah anak yang terkena masalah tersebut menjadi bagian dari 87 juta anak yang ada dan tersebar di seluruh pelosok tanah air, baik di perkotaan maupun di pedesaan.

Penyebaran narkoba hingga kini sudah hampir tidak bisa dicegah. Mengingat hampir seluruh dunia dapat dengan mudah mendapat narkoba dari oknum-oknum yang tidak bertanggung jawab. Misalnya saja, dari Bandar narkoba yang senang mencari mangsa di daerah sekolah, diskotik, tempat pelacuran, dan tempat-tempat berkumpulnya anak -anak muda. Tentu hal ini sangat memprihatinkan siapapun termasuk para orang tua, guru, ormas bahkan 
pemerintah. Generasi muda kerap menjadi sasaran utama dalam peredaran narkoba. Mereka ingin menyerang mental generasi muda ini dengan memanfaatkan kuatnya rasa ingintahu yang di miliki generasi tersebut. Hal ini yang menyebabkan banyak generasi muda rawan menjadi sasaran peredaran narkoba. Direktur Diseminasi Informasi Deputi Bidang Pencegahan Badan Narkotika Nasional (BNN), Gun Gun Siswandi mengatakan, faktor ketertarikan generasi muda merupakan penyebab tertinggi para pengedar narkoba sangat mudah menawarkan Narkoba kepada mereka. Generasi muda sangat rentan terhadap penyalahgunaan narkoba karena pada ini emosi mereka masih labil dan rasa ingin tahu cukup tinggi.

Ketiga, Penyalahgunaan mengkonsumsi minuman keras berada tingkat mengkhawatirkan. Penyalahgunaan narkoba merupakan permasalahan yang cukup berkembang di dunia remaja. Mereka terkadang merasa bangga dengan predikat sebagai pengguna narkoba. Penyalahgunaan penggunaan narkoba menunjukan kecenderungan meningkat dari tahun ke tahun. Peningkatan ini membawa dampak signifikan, sehingga dampaknya sangat dirasakan dalam kehidupan masyarakat. Dampak yang paling dekat dalam bentuk kenakalan-kenakalan anak remaja. Mereka sering melakukan perkelahian, munculnya geng-geng remaja, perbuatan asusila, dan maraknya premanisme pada kalangan remaja. Minuman keras adalah minuman yang memabukkan. Para peminum minuman keras dapat hilang kesadarannya. Zulvikar dalam Verdian Nendra Dimas Pratama mengatakan bahwa yang disebut minuman keras itu sejenis arak (khamr). Minuman yang termasuk jenis ini seperti wine, whisky brandy, sampagne, malaga, dan lain-lain. Minuman keras juga minuman-minuman yang beralkohol yaitu minuman yang mengandung etanol. Etanol adalah bahan psikoaktif. Seseorang yang mengkonsumsi bahan-bahan yang mengandung seringkali mengalami penurunan kesadaran. Di beberapa negara minuman ini dibatasi penjualannya pada kalangan tertentu saja. Orang yang diperkenankan mengonsumsi, biasanya telah melewati batas usia tertentu.

Hasil survei Dinas Penelitian dan Pengembangan (DISLITBANG) Polri menunjukkan bahwa pemakai narkoba dan minuman keras di Indonesia secara nasional terbanyak dari golongan pelajar. Pelajar yang dimaksud bukan berarti terkonsentrasi pada jenjang tertentu, melainkan menyebar. Mereka terdiri dari siswa-siswi yang sedang belajar di jenjang SLTP, SLTA, bahkan mahasiswa. Dari kelompok tersebut pemakai narkoba jumlahnya mencapai $70 \%$. Adapun pemakai narkoba dari kelompok setingkat SD 30\%. Capaian sebanyak itu sebagian besar dari mereka berasal dari anak yang orang tuanya memiliki latarbelakang ekonomi menengah ke atas (penelitian ini dilakukan pada tahun 2012).

Keempat, Perilaku seks bebas atau seksual pranikah pada usia remaja (15 24 tahun) di Indonesia cenderung meningkat, hal itu akibat belum optimalnya pendidikan keluarga sejahtera dan rendahnya tingkat pemahaman para remaja terhadap resiko hubungan seks diluar nikah. Kecenderungan kenaikan itu dapat dilihat dalam survey Demografi dan kesehatan Indonesia (SDKI) tahun 20072012. Masalah seks bebas sudah sangat mengkhawatirkan, karena makin banyaknya jumlah bayi yang dilahirkan dibuang di jalanan. Indonesia Police Watch (IPW) mencatat sepanjang 2017 ada 178 bayi yang baru dilahirkan kemudian dibuang di jalan. Jumlah ini naik 90 kasus dibanding tahun 2016, seperti yang dikatakan oleh Ketua Presidium Indonesia Police watch (IPW), Neta S Pane. Bayi yang dibuang oleh orang tuanya itu paling banyak terjadi di wilayah hukum Polda Metro Jaya, denga 27 kejadian. Kemudian disusul Jawa Timur 
berada di posisi keduanya, dengan 24 kasus dan Jawa Barat di posisi ketiga dengan 23 kasus kejadian. Yang mengrejutkan adalah Aceh, provinsi yang sudah menggunakan syari'at Islam ini terdapat kasus pembuangan anak jumlahnya cukup signifikan yaitu sekitar 16 kasus. Berarti Aceh merupakan wilayah yang tertinggi di luar Jawa kasus pembuangan bayi ini, dan kemudian adalah Sumatra Utara dengan 8 kejadian. Kasus ini terjadi sepanjang tahun 2017 lalu. Kasuskasus di atas, ironinya bukan hanya terjadi sebelum adanya kampanye pendidikan karakter tapi banyak terjadi justru setelah didengungkan pendidikan karakter

\section{PEMBAHASAN}

Kegiatan pembelajaran disebut memenuhi kriteria living value education (LVE), apabila memenuhi indikator-indikator yang diinginkan. Rincian indikator yang terkumpul menjadi satu, menggambarkan keutuhan makna. Oleh karena itu, untuk menemukan pemahaman yang utuh tentang LVE bagi anak, menghendaki temuan indikator-indikator. Indikator tersebut selanjutnya dilakukan kajian dan pembahasan.

Pembahasan yang dimaksud adalah menggali makna living value education bagi anak. Makna living value menempati awal urutan pembahasan. Perdebatan-perdebatan tentang value, living value, value education juga dibahas dalam bab ini.

Di dunia barat pergumulan pemikiran tentang nilai, moral dan etika, para ilmuan barat mempunyai konsep yang sangat berbeda satu dengan lainnya. Ini merupakan sebuah konsekwensi dari sekularisasi Eropa setelah hilangnya kepercayaan masyarakat barat terhadap kepemimpinan gereja. Sekularisasi sangat berdampak pada pemisahan agama dengan berbagai aktifitas kehidupan. Seperti politik, ekonomi juga pendidikan. ${ }^{1}$

Sedangkan nilai dalam pandangan ilmuan timur (Islam) bahwa nilai tidak terlepas dari posisi agama yang memiliki peranan penting dalam menjaga keseimbangan kehidupan, khususnya pembinaan karakter manusia . nilai-nilai yang terkandung dalam ajaran Islam merupakan sumber dan tolok ukur dari segi standarisasi karakter manusia. Standarisasi tersebut merupakan kandungan ajaran al-Qur'an yang di refelksikan dalam bentuk nyata dalam kehidupan sehari-hari yang dicontohkan oleh akhlak Rasulullah Sallallahu 'alaihi Wasaallam. Melalui sunnah-sunnahnya, yaitu nilai-nilai yang berbentuk keimanan, ketakwaan, keadilan, yang diabadaikan dalam wahyu Allah SWT. ${ }^{2}$

Pendidikan living value merupakan proses terwujudnya living value pada realitas kehidupan peserta didik. Proses penanaman, pemahaman, dan pengamalan living value. Untuk itu, pembahasan LVE harus dimulai dari penjelasan tentang living value.

Value (Inggris) secara etimologi, bermakna nilai atau "velere" dalam bahasa latin dan "valoir" dalam bahasa Perancisnya, dapat diartikan berguna, mampu , berdaya , kuat, baik , bermanfaat dan paling benar menurut keyakinan seseorang ataun kelompoknya. ${ }^{3}$ Nilai bersifat abstrak seperti sebuah ide, tidak dapat ditangkap dengan indera, yang dapat ditangkap oleh indera adalah objek yang memiliki nilai. ${ }^{4}$ Value berdasarkan pemahaman istilah (terminology)dapat dipahami dengan berbagai makna. Dan juga berbagai pendapat. Sekurangkurangnya, value disebagai etika atau ekonomi. Keduanya memiliki arti berbeda. Dalam pandangan etika, nilai menunjukkan tingkat penting perilaku, sikap, tindakan, maupun ucapan seseorang. Menurut Edwards dalam Holbrook menyebutkan bahwa nilai merupakan norma pribadi yang digambarkan dalam 
bentuk keyakinan terhadap apa yang seseungguhnya dibutuhkan, diinginkan, dan yang seharusnya dilakukan. Edwrds menjelaskan bahwa "A value is a personal norm a belief about what is needed, wanted, or ought to be". 5

Bambang Daroeso (1986) mengatakan bahwa nilai adalah suatu kualitas atau pengharagaan terhadap sesuatu, untuk dijadikan tolok ukur mengetahui sikap dan perilaku manusia.. Darji Darmodiharjo (1995) mengatakan bahwa nilai adalah ukuran kualitas atau keberadaan sesuatu yang bermanfaat bagi manusia, baik lahir maupun batin 7 . Widjaja (1984) berkata lain bahwa menilai berarti menimbang atau mengukur, merupakan aktifitas yang menghubungkan. Konsepsi nilai dalam peradaban barat seperti disebutkan diatas mempunyai pandangan yang berbeda satu dengan lainnya hal tersebut diakibatkan dengan adanya sekularisasi kehidupan. Dalam penelitian ini penulis membatasi beberapa pendapat ilmuan yang merupakan perwakilan dari priodesasi waktu kehidupan yang mereka hidup didalamnya. Periodesasi yang dimaksud yaitu masa abad pertengahan (medieval age), masa renaisans, dan masa pencerahan, seperti yang ditulis oleh Dinar Dewi.

Pertama, masa pertengahan (medieval age). Yaitu masa ketika doktrin Kristen ditetapkan oleh otoritas tradisi sebagai sumber kebenaran yang absolut yang harus diterima tanpa pertanyaan. Ada salah satu filosof pada abad pertengahan yang mencoba menggabungkan etika Kristen dengan filsafat Yunani, yaitu Thomas Aquinas (12225-1274).

Kedua, masa renaisans. Yaitu terjadi pada abad ke-16 yang dimaknai sebagai kelahiran kembali peradaban Yunani-Romawi yang para ilmuannya sangat menekuni aliran ini dan bertentangan dara para ilmuan penekun teologi

Kristen Barat. ${ }^{12}$ Pada abad ke 17 muncullah aliran filsafat rasionalisme dan empirisme yang menganggap bahwa sumber pengetahuan semata-mata berasal dari akal (rasional) dan pengalaman (empiris.) Tokoh yang sangat berpengaruh dalam aliran ini adalah Rene Descrates (1596-1650). Descartes tidak mengajari etika secara khusus namun hanya memberi pandangan-pandangan etis dengan mengandaikan adanya kehendak bebas.

Ketiga, masa pencerahan, masa ini diperkiranakan dimulai pada abad ke18. Merupakan masa yang mereka mulai meneliti dengan kritis sesuai dengan kaidah-kaidah yang dihasilkan dari akal pikiran. Mereka sudah tidak takut lagi mengeritik bahkan mencela terhadap pemikiran yang berbeda baik yang terjadi di Negara dan masyarakat. Sementara kebijakan gereja pada saat itu lebih banyak menolak, karena mereka lebih mendahulukan akal sebagai sumber kebenaran. David hume merupakan tokoh pencerahan di Inggris yang mengembangkan filsafat empirisme. Filsafat Hume merupakan kritik terhadap rasionalisme dogmatis decorates.

Sedangkan nilai dalam pandangan ilmuan timur (Islam), walaupun terdapat adanya beberapa perbedaan, mereka konsiten sumber agama dijadikan standar dalam memaknai nilai. bahwa nilai tidak terlepas dari posisi agama yang memiliki peranan penting dalam menjaga keseimbangan kehidupan, khususnya pembinaan karakter manusia. Nilai-nilai yang terkandung dalam ajaran Islam merupakan sumber dan tolok ukur dari perilaku atau moralitas. Nilai juga dapat dipahami dari makna padanan katanya yang bersumber dari bahasa Arab al-qîmah. Al-qîmah (( berasal dari akar kata " ف مان artinya $i$ 'tadala (tegak) dan hilang ketidak lurusannya. Dari makna ini terdapat kata Istâqama al-amru artinya baik dan hilang penyimpangannya. Qîmat asy- sya'i berarti ukuran/ kadar sesuatu, qîmah al-mata' berarti harga perhiasan, ummah al-qayyimah berarti umat yang 
lurus dan berkeadilan. Dalam QS. al- Bayyinah/ 98: 5, yang artinya

\section{"Dan yang demikian itulah agama yang lurus"}

Bentuk plural dari al-Qîmah adalah al-Qiyam (مُقئل) dalam kamus- kamus bahasa Arab tidak terlepas dari makna al-Qaumah " "قموقل ". Ini dapat diartikan dengan istilah bangkit "al-Nahdhah", al-Qawim (ميونل) artinya adil, lurus, tegak. Dan makna al-Qawîm (ماوقل) artinya adalah adil atau seimbang seperti dalam alQur'an surat al-Furqân: 67: yang artinya

"Dan adalah (pembelanjaan itu) di tengah-tengah antara yang demikian".

Dalam ayat di atas, terdapat kalimat qawặmặ. Kalimat ini memberikan penekanan terhadap susunan kalimat sebelumnya. Kalimat ini, memiliki makna tersendiri, dengan memandang kalimat yang sama maupun kalimat serupa. Alqayyûm, al-qâim, berarti pemelihara akan segala sesuatu. Kitab qayyim artinya buku yang berharga.

Tabel.II. I

Pengertian Value dalam Bahasa (etimologi)

\begin{tabular}{|l|l|}
\hline \multicolumn{1}{|c|}{ Nilai } & \multicolumn{1}{|c|}{ Pengertian } \\
\hline $\begin{array}{l}\text { Value ( Inggris) Velere (LatinBerguna, mampu akan... berdaya berlaku } \\
\text { Valoir (Prancis) } \\
\text { bermanfaat, paling benar menurut keyakinas } \\
\text { seseorang atauy kelompoknya. }\end{array}$ \\
\hline $\begin{array}{l}\text { al-Qîmah (Arab) bersal } \\
\text { kata qâma dan bentuk } \\
\text { pluralnya al- qiyam }\end{array}$ & $\begin{array}{l}\text { Tegak,hilang ketidak lurusannya, ukuran, kadar } \\
\text { sesuatu, dan bangkit. }\end{array}$ \\
\hline
\end{tabular}

Tabel II. II

Pengertian Value dalam Ekonomi dan Etika

\begin{tabular}{|c|c|}
\hline Nilai dalam etika & Nilai dalam ekonomi \\
\hline $\begin{array}{l}\text { Nilai menunjukan tingkat penting akal } \\
\text { perilaku, sikap, tindakan, maupu } \\
\text { ucapan seseorang. Nilai etika tida } \\
\text { berubah baik dan buruknya karen } \\
\text { keadaan. Tidak terpengaruh denga } \\
\text { situsai dan kondisi. Nilai adalah sesuat } \\
\text { yang harus diperjuangkan dan sebalikny } \\
\text { yang harus dihindari. }\end{array}$ & $\begin{array}{l}\text { Nilai dalam ekonomi adalah sesuat } \\
\text { objek yang dapat ditukar, bisa nai } \\
\text { bisa turun, tergantung faktor-fakto } \\
\text { yang mempengaruhi. }\end{array}$ \\
\hline
\end{tabular}

Urgensi nilai-nilai dalam kehidupan bermasyarakat dan berbangsa, untuk menjadikan kehidupan yang manusiawi itu terlihat dari standar aturan yang membatasi hubungan mereka diantara individu dan pola interaksi diantara mereka dalam berbagai aktifitas kehidupan. Lestari dan tidaknya hubungan mereka dalam bermasyarakat tergantung dari mampunya mereka dalam menjaga nilai-nilai kehidupan yang ada dilingkungannya. Nilai dalam makna etika, dapat digolongkan sebagai hal positif. Nilai menunjukkan sesuatu yang harus diperjuangkan dan sebaliknya adalah sesuatu yang harus dihindari. Hal yang menjadi lawan dari nilai 
dianggap mengurangi kepercayaan diri dan menghalangi untuk mempertahankan harga diri yang tinggi. Oleh karena itu, seseorang berusaha menghilangkan perilaku yang menipu, tidak tulus, tidak adil atau menyakiti orang lain. Seseorang ingin memiliki sesuatu yang positif dan menghindari apa yang dianggap negatif, yang meminggirkan seseorang di antara anggota masyarakat lainnya. Karena itulah, hampir semua orang memiliki keinginan untuk melakukan kebaikan, walaupun kebaikan itu adalah kebaikan menurut dirinya sendiri. Ada keyakinan dalam diri hampir semua orang, bahwa kebaikan akan kembali kepada dirinya sendiri. Seseorang berbuat baik kepada tetangganya, karena meyakini akan dibalas kebaikan oleh tetangga itu. Bahkan, pimpinan penjahatpun berbuat baik kepada anak buahnya, agar memperoleh imbalan kesetiaan dari anak buah tersebut. Selain dalam arti etika, nilai dapat dipahami dalam arti lain yang berbeda sama sekali. Nilai dalam pandangan etika dibedakan dengan nilai ekonomi. Nilai etika tidak tergantung pada kondisi maupun komoditas yang diinginkan.

Sekalipun demikian, nilai ekonomi seringkali dianggap sebagai hasil dari nilai etika. Nilai etika seseorang dapat mempengaruhi nilai ekonominya. Misalnya, nilai yang diberikan oleh masyarakat kepada seseorang dai ketika menyampaikan ceramahnya, lebih memiliki hubungan erat dengan nilai ekonomi sebagai imbalan langsung. Darmadi memiliki pendapat serupa dengan Djahiri. Darma di berpendapat dalam Kokom Komalasari dan Didin Saripudin, nilai diyakini sebagai sesuatu yang berharga. Istilah berharga dapat dipandang penghargaannya terhadap logika baik menurut standar logika sebagai segala sesuatu yang benar atau salah. Standar nilai juga berupa standar estetika, suatu benda dapat dinilai bagus atau buruk.

Terkait denga nilai-nilai kehidupan, Mundil berpendapat bahwa Islam memberi perhatian tinggi terhadap nilai. Menurut Mundil, tidak ada agama manapun yang memberikan perhatian sangat tinggi terhadap nilai-nilai kehidupan manusia dari pada Agama Islam. Islam menjaga keberlangsungan hidup manusia. Dalam Islam, jiwa seseorang dilindungi. Pembunuhan terhadap seseorang sangat keras larangannya. Pembunuhan pada satu orang, dalam al- Qur'an, berarti sama saja dengan meniadakan atau membunuh semua manusia. Sebalikanya, orang yang menghidupkan satu orang sebanding dengan menghidupkan semua orang. AlQur'an bahkan menjadikan nilai-nilai kehidupan manusia sebagai salah satu standar transendental dari maksud atau tujuan diberlakukannya syariat (Maqâsid asy-Syari'ah).

Konsep penjagaan terhadap kehidupan manusia, dituangkan di dalam QS. Al-Mâidah/ 5: 32, yang artinya: "Oleh karena itu, Kami tetapkan (suatu hukum) bagi Bani Israil, bahwa: barangsiapa yang membunuh seorang manusia, bukan karena orang itu (membunuh) orang lain, atau bukan karena membuat kerusakan dimuka bumi, maka seakan-akan dia telah membunuh manusia seluruhnya. Dan barangsiapa yang memelihara kehidupan seorang manusia, maka seolah-olah dia telah memelihara kehidupan manusia semuanya. Dan sesungguhnya telah datang kepada mereka rasul-rasul Kami dengan (membawa) keterangan-keterangan yang jelas, kemudian banyak diantara mereka sesudah itu sungguh-sungguh melampaui batas dalam berbuat kerusakan dimuka bumi”.

Dalam ayat tersebut, jelas menggunakan kalimat qatala, yang sering diartikan dengan membunuh. Seseorang terancam hukum balasan yang sangat berat bagi pembunuh. Bahkan, pembunuhan yang menghilangkan nyawa satu orang saja dianggap telah melakukan pembunuhan kepada semua orang. Karena, 
pembunuhan terhadap seseorang berarti telah menghilangkan hak hidup bagi calon keturunan yang masih ada dalam diri orang tersebut.

Nilai-nilai kehidupan merupakan nilai-nilai universal. Nilai ini secara potensial sudah termuat dalam agama-agama besar. Bahkan, nilai tersebut dapat dikaitkan dengan agama. Dapat dikatkan bahwa agama-agama itulah yang membuka wawasan martabat manusia sebagai manusia. Agama bukan hanya sekedar mengajarkan manusia sebagai warga suku, kelompok, atau kelas sosial tertentu. Mereka diajarkan dogma-dogma yang mengantarkan manusia menuju derajat kemanusiaannya. Agama-agama besar berbicara tentang manusia. Manusia akan berada dalam posisi sebagai manusia apabila mereka bicara tentang yang ilahi. Dalam etika global, salah satu nilai penting yaitu adanya kesamaan nilai-nilai kemanusiaan. Walaupun realitasnya ada perbedaan, justru perbedaan tersebut dalam suatu agama dan tradisi dapat dijadikan dasar bagi pergaulan antarumat manusia. Pembicaraan tentang kehidupan manusia, misalnya dalam Islam diajarkan dengan ajaran cinta kasih. Bahkan dalam suatu ketika Rasulullah Sallâllahu 'alaihi wasallam menyampaikan pesan bahwa keimanan seseorang dipandang dari kecintaannya kepada orang lain. Seseorang dianggap keimanannya tidak sempurna ketika dasar cinta itu tidak diperoleh. Seseorang dapat diukur keimannya dengan cara ukuran keimanan dengan orang lain. Sabda Nabi "Dari Anas bin Malik RA. Dari Nabi Muhammad Sallallahu 'alaihi Wasaallam. Tidak (sempurna) iman seorang dari kalian sehingga dia mampu mencintai saudaranya seperti dia menicintai dirinya sendiri. (.H.R. al- Bukhari)”.

Ajaran yang hampir serupa atau bahkan dengan maksud yang sama juga disampaikan oleh Yesus. Dalam suatu kesempatan, Yesus juga menyampaikan bahwa seseorang yang menginginkan sesuatu hendaknya melakukan hal serupa kepada orang lain. Yesus memberikan penjelasan lebih detil tentang keinginannya yang sangat mungkin terikat dengan. Seperti halnya Yesus, Budha menyampaikan bahwa keadaan yang tidak menyenangkan ataupun menyenangkan baginya akan juga demikian bagi orang lain. Menurut Budha, seseorang tidak mungkin dapat memberikan beban kepada orang lain dengan keadaan yang tidak menyenangkan bagi dirinya sendiri. Hindu tidak berbeda dengan ajaran agama lainya. Ajaran tatakerama kesusilaan Hindu terdapat pada ajaran Hindu Dharma. Ajaran tersebut di antaranya adalah Tat Twam Asi yang artinya "Dia adalah kamu, saya adalah kamu, dan semua makhluk adalah sama" Sehingga bila kita menolong orang lain berarti menolong diri kita sendiri (kitab veda) dengan demikian semua agama mengajarkan kebajikan, cinta kasih, keadilan, dan menentang setiap bentuk agresi dan kekerasan.

Rasulullah Sallallâhu 'alaihi wasallam ketika merekonstruksi Madinah sebagai pusat kekuasaan dan melakukan transformasi besar-besaran yang meliputi berbagai macam aspek kehidupan. Hal yang dianggap paling urgen dari transformasi nilai ini adalah terkait penanganan masalah sosial (sosial problem). Masyarakat Madinah yang heterogen, dan pluralis baik suku dan agama menjadikan tugas Rasulullah semakin menarik untuk dikaji.

Rasulullah sallallâhu 'alaihi wasallam melakukan tahapan-tahapan dalam memimpin Kota Madinah. Beliau mereformasi situasi dan kondisi masyarakat Madinah yang sebelumnya bersuku-suku dan saling bermusuhan. Ashobiyah atau primordialisme itu dapat rukun, damai, dan bersaudara. Di sana Rasulullah Sallallâahu 'alaihi wasallam melaksanakan beberapa langkah strategis yaitu: Pertama Beliau mempersaudarakan (al-Ikhâ) antara dua orang atau komunitas kelompok yang berbeda. Masyarakat Muhajirin yang datang dari Kota Mekah 
dipersaudarakan dengan masyarakat asli Madinah. Kedua Rasulullah menanamkan nilai-nilai kasih sayang (al-mahabbah) antara komunitas masyarakat di Madinah. Jiwa mereka dipenuhi oleh ajaran-ajaran. Rasulullah yang penuh kasih dan sayang. Ketiga Rasulullah dengan tegas menegakkan nilai-nilai keadilan (al'adâlah) yang merupakan landasan pembentukan konstruksi masyarakat dan warga Madinah. Keempat Rasulullah menanamkan nilai-nilai persamaan (al-Musâwâh) antara warga masyarakat Madinah dalam hak dan kewajiban tanpa membedakan ras, suku, dan agama.

Kearifan lokal yang mendekati nilai-nilai universal adalah: pandangan hidup masyarakat Jawa Barat (cageur, bageur, bener, singer, pinter, maher, dan moher). Contoh lain, Masyarakat Minagkabau yang memiliki tujuan membentuk masyarakat yang aman, damai, sejahtera dan berkah. Dengan menggunakan Living Values: A Guide Book dan "Convention on the Rights of the Child" (Konvensi Hak Anak) sebagai kerangka kerja, para pengajar mengidentifikasikan dan menyetujui tujuan pendidikan berdasarkan nilai di seluruh dunia, baik di negara-negara yang sudah berkembang dan yang sedang berkembang. Living Values Educators' Kit (panduan pendidikan nilai pendidik ) siap digunakan pada bulan Februari 1997, dan semenjak itulah Living Values telah mulai dijalankan.

Living Values Education pertama kali diperkenalkan di Indonesia pada tahun 2002. Pada awalnya, aktivitas Living Values Education diinisiasi secara personal oleh beberapa trainer yang telah mengikuti pelatihan bersama $L V E$ Internasional. Berbagai kegiatan, seminar dan pelatihan Living Values Education kemudian dilakukan di banyak kota di Indonesia. Mulai dari Banda Aceh, Jakarta, Bogor, Bandung, Subang, Sukabumi, Yogyakarta, Salatiga, Solo, Kupang, Tabanan, Singaraja, sampai di Ambon dan Ternate. Program dan aktivitas Living Values Education tersebut tidak hanya dilakukan dalam lingkungan pendidikan, namun juga di camp pengungsian, dalam komunitas maupun institusi lainnya. Pada tanggal 1 Desember 2008, Yayasan Karuna Bali ditunjuk menjadi perwakilan Asosiasi Living Values Education di Indonesia oleh ALIVE (Asosiasi LVE) Internasional. Yayasan Karuna Bali mengemban tugas sebagai payung hukum, mengeluarkan akreditasi pelatih dan mengkoordinasi kegiatan-kegiatan Living Values Education di Indonesia.

Setidaknya ada duabelas nilai dalam Living Value Education, yaitu: kedamaian, penghargaan, kasih sayang, toleransi, kerendahan hati, kejujuran, kerjasama, kebahagiaan, tanggungjawab, kesederhanaan, kebebasan, dan persatuan. Ke-duabelas nilai tersebut adalah nilai-nilai yang harus ada dalam Living Value Education Program (LVEP), walaupun tidak menutup kemungkinan ada nilai-nilai lain dari duabelas nilai tersebut di atas.

Dalam Islam pendidikan bertujuan untuk mencapai pertumbuhan keperibadian manusia yang menyeluruh secara seimbang melalui latihan jiwa, intelektual, perasaan, dan indera. Oleh karena itu, pendidikan harus mencapai pertumbuhan manusia dalam segala aspeknya, baik spiritual, intelektual, imajinatif, fisik, ilmiah, bahasa, secara individu maupun kolektif, serta mendorong semua aspek ini ke arah kebaikan dan kesempurnaan. tujuan akhir pendidikan Islam terletak dalam perwujudan ketertundukan yang sempurna kepada Allah Subhânahu wata'âla, baik secara pribadi, komunitas maupun seluruh umat manusia. Pendidikan adalah proses pembudayaan, proses kultural, atau proses kultivasi untuk mengembangkan semua bakat dan potensi manusia guna mengangkat diri sendiri dan dunia sekitarnya pada taraf human, taraf human yang dimaksud adalah yang terkandung dalam pengertian bagaiman pendidikan bisa mengangkat derajat manusia ke arah yang bermoral, bermartabat, berkarakter 
baik, mempunyai nilai (values) serta sikap yang mencerminkan bahwa manusia adalah insan kamil yang sebenarnya.

Ciri-ciri dari insan kamil adalah mempunyai sikap yang bukan hanya mampu mengatur hidupnya dengan sang Pencipta, yaitu Allah Subhânahu wata'âla secara vertikal tapi juga mempunyai kemampuan untuk dapat menjamin hidup bersama secara damai sesama manusia secara horizontal meskipun dengan adanya keragaman pada lingkungannya, dengan tidak menyakiti siapapun baik secara lisan dan tangannya(perilakunya). Seperti sabda Nabi Muhammad SAW. Yang artinya

Dari Abdillah bin Amr ra, dari Nabi Muhammad SAW bersabda: Seorang Muslim adalah orang yang Muslim lainnya merasa aman/ selamat dari (gangguan) lidahnya dan tangannya (perbuatannya). H.R. Al-Bukhâri bab al- Shiyâm hadits nomor 10. Dalam riwayat Muslim bahwa seoarang laki-laki bertanya kepada Rasullah SAW, "Muslim manakah yang yang baik? Rasulullah bersabda: adalah orang Muslim lainnya merasa aman/ selamat dari lisannya dan tangannya) H.R. Muslim.

Setiap individu diajak untuk memikirkan dan merefleksikan nilai-nilai yang berbeda. Implikasinya berupa implikasi praktis bila mengekspresikan nilainilai tersebut dalam hubungannya dengan diri. Setiap peserta diarahkan untuk mampu menginspirasi diri sendiri, orang lain, masyarakat, dan seluruh dunia. Selain itu, peserta juga diperintahkan untuk memperdalam pemahaman tentang nilai. Mereka diarahkan agar mampu menjaga keseimbangan motivasi dan tanggung jawab. Mereka harus tetap terjaga motivasinya, saat menentukan pilihanpilihan pribadi dan sosial yang positif.

Nilai kehidupan perlu daiajarkan. Hal ini dilakukan untuk mendorong para pengajar dan pengasuh memandang pendidikan sebagai sarana memberikan filsafat-filsafat hidup. Materi tersebut diajarkan kepada murid, dengan demikian memfasilitasi pertumbuhan, perkembangan, dan pilihan- pilihan mereka sehingga mereka bisa berintegrasi dengan masyarkat dengan rasa hormat, percaya diri, dan tujuan yang jelas. Dari tujuan-tujuan LVE di atas, maka tujuan-tujuan LVE sangat mendukung dalam orientasi pengembangan kinerja para pendidik khususnya guru, dalam hal ini dari sisi kepribadian guru tersebut karena guru tidak hanya berorientasi pada diri mereka sendiri tetapi juga lebih peka terhadap sesama dan lingkungannya.

Dalam Undang-Undang Nomor 14 Tahun 2005 tentang guru dan dosen, kemampuan seorang guru untuk mampu membentuk karakter anak didik adalah menjadi keniscayaan. Maka guru harus mempunyai kompetensi keperibadian dan sosial, disamping kompetensi pedagogic dan professional. Guru mempunyai kedudukan yang sangat dominan karena aktifitas guru akan menjadi sumber rujukan masyarakat terutama masyarakat terutama mereka yang masih berstatus pelajar. Menjadi pendidik tidak cukup dengan ilmu pengetahuan saja, seorang guru harus menganggap anak didiknya sebagai anaknya sendiri.yang mereka kader dengan penuh tanggung jawab agar kelak mereka menjadi manusia yang berguna bagi nusa dan bangsanya. Perjuangan seorang guru layaknya perjuangan seoarang pahlawan berejuang untuk masa depan dan kesejahteraan bangsanya. Indonesia merupakan bangsa yang besar, yang membutuhkan generasi yang berkarakter yang mampu mempertahankan kesatuan dan persatuan bangsa.

Salah satu proses mendasar dalam program pelatihan Living Values 
Education adalah tiap pendidik juga diajak untuk merefleksikan dan menggali nilai pribadi mereka, agar dapat menjadi pondasi dalam menciptakan suasana belajar yang berbasis nilai. Living Values Education percaya bahwa nilai tidak diajarkan, melainkan ditangkap atau dirasakan. Murid belajar dari contoh yang diberikan pendidiknya. Oleh karena itu, sangat penting bagi tiap pendidik untuk menyadari dan terus menghidupkan nilai pribadi mereka, untuk dapat menjalani peran sebagai panutan ini secara positif.

\section{PENUTUP}

Pertama, living value education merupakan program pendidikan yang menawarakan aktivitas nilai-nilai empiris dan metodologi praktis bagi para pendidik, orang tua, untuk menggali dan mengembangkan dua belas nilai universal yaitu, kerjasama, kebebasan, kebahagiaan, kejujuran, kerendahan hati, cinta, kedamaian, penghargaan, tanggung jawab, kesederhanaan, toleransi, dan persatuan. Nilai-nilai ini berupa nilai-nilai religious, nasionalis, integritas, kemandirian, toleransi, dan gotong royong.

Nilai-nilai kehidupan tersebut harus diajarakan kepada anak sejak lahir hingga umur 18 tahun (akil baligh), agar dijadikan keperibadian bagi anak didik. karena dalam jenjang ini mereka memiliki egosentris yang cukup tinggi. Anak cenderung tidak memiliki kemauan untuk melihat banyak hal dari sudut pandang orang lain. Dalam kondisi demikian, living value education tepat diberikan kepada mereka. Pembatasan umur anak dalam penelitian ini berdasar term-term al-Qur'an terkait dengan anak memberikan petunjuk akan hal tersebut. Term walad menunjukan anak yang dilahirkan menunjukan adanya hubungan nasab,bahkan walad juga dapat digunakan untuk anak angkat. Dan term walad tidak membatasi anak tersebut masih kecil ataupun sudah besar. Term ibn yang artinya anak laki-laki atau bint anak perempuan term ini terambil dari akar kata banau bentuk pluralnya adalah abna penyebutan tersebut dalam bahasa Arab dimungkinkan adanya anak merupakan bangunan bagi orang tuanya. Orang tua sebagai sosok untuk membangunnya. Allah menjadikan orang tua sebagai pendiri bangunan untuk mewujudkan terlahirnya keturunan. Sedangkan tifl (anak kecil yang baru dilahirkan, kata thiflu berarti anak yang masih kecil yang memerlukan bimbingan dan asuhan.dan term gulâm sebagai anak remaja berusia diantara 10 sampai 20 tahun atau usia lahir sampai memasuki usia remaja.Secara semantic berarti anak yang sudah mulai puber dan berkobar nafsu birahinya. Dari termterm ini dapat disimpulkan bahwa yang tergolong usia anak adalah sejak kelahirannya hingga akil baligh, mereka sangat membutuhkan pendidikan dan membangunnya agar mapan dan mandiri. Maka Strata pendidikan dasar merupakan jenjang yang tepat untuk memperkuat dasar-dasar living value education hal ini merupakan basic dari penanaman keperibadian.

Kedua, living value education merupakan salah satu pengembangan model pembelajaran dari pendidikan karakter yang menanamkan prinsip belajar mengutaamakan moralitas dengan menerapkan dua paradigma, yaitu penanaman nilai- nilai-nilai pada pribadi-pribadi peserta didik. Dan menanamkan nilai-nilai kehidupan bersama dengan damai dan toleran. Dan kedua paradigm tersebut tidak akan berhasil kecuali melalui proses penanaman nilai-nilai kehidupan. Dan LVE ini dapat diintegrasikan melalui proses pembelajaran intrakurikuler, kokulikuler, dan ekstra kurukuler di lembaga-lembaga pendidikan. LVE yang diajarakan kepada anak didik untuk membangun karakter anak adalah, penanaman nilai-nilai religious, membangun dimensi inteketual, (IQ), dimensi emotional spiritual (SQ), dimensi emosional (EQ), dan dimensi advrsitas(AQ). Menanamkan nilai- 
nilai budaya dan norma-norma berbangsa dan Bernegara,

Ketiga, dalam penelitian ini ditemukan bahwa konsep al-Qur'an Sejak alQur'an diturunkan membawa missi yang sangat padat dengan nilai-nilai kehidupan . LVE sangat sejalan dengan maqashid al-Qur'an (tujuan-tujuan alQur'an diturunkan). Maqashid al-Qur'an berisikan perbaikan kehidupan secara pribadi, perbaikan kehidupan bersama dan perbaikan tatanan kehidupan yang lebih luas). Dan ketiga maslahah ini merupakan kebutuhan dasar manusia dimanapun dan kebutuhan dasar manusia ini tidak terepas dari lima prinsip hidup yaitu memlihara agama memelihara jiwa memelihara akal), memelihara keturunan, dan memelihara harta. Al-Qur'an memberikan inspirasi akan konsep syariat yang dapat dijadikan sebagai pendidikan nilai dalam al-Qur'an. Diantara pendidikan nilai tersebut adalah prinsip tidak memberatkan, mengurangi beban dan prinsip aturan yang bersifat gradual.

Keempat, Model implementasi pendidikan nilai kehidupan pada anak berbasis al-Qur'an, dalam penelitian ini penulis menemukan dua model. Yang pertama, pendidikan nilai yang dilakukan bagi anak pra sekolah. Dalam sub ini penulis mengungkap tentang pentingnya peran ibu yang mempunyai multi peran yang tidak terbatas sebagai ibu, namun juga sebagai pendidik nilai kehidupan yang pertama bagi anak.khususnya pendidikan anak pra sekolah Dan disamping juga ibu mempunyai hak untuk berperan diluar rumah untuk bekerja di ruang publik seperti laki-laki . Dalam sub ini terungkap perdebatan- perdebatan para ulama yang terakait dikotomi boleh tidaknya seorang ibu berperan diluar rumah.penulis dalam perdebatan ini mendukung pendapat Ibnu Katsir, Muhamad Quthb, Nasaruddin Umar, dan Nur Arfiyah Febriani yang membolehkan perempuan beraktifitas diluar public dengan persyaratan- persyaratannya. Dan berbeda dengan pendapat alQurthuby dan Jalâluddin as- Suyûthy yang menolak perempuan untuk beraktifitas di wilayah public. Yang kedua, dari model imlementasi pendidikan nilai berbasis al-Qur'an adalah pendidikan nilai kehidupan bagi anak melalui sekolah. Pembahasan sub bab ini menitik beratkan kepada pendidikan nilai kehidupan seiring dengan perkembangan dan pertumbuhan anak. Melalui jalur lembaga pendidikan formal. Untuk menuju kearah tersebut Penulis mengungkap perlunya pengembangan dan keseimbangan pendidikan nilai-nilai kecerdasan yang secara umum mempengaruhi kehidupan yaitu kecerdasan akal (IQ), kecerdasan emosi (EQ), kecerdasan ketahanan mental( $\mathrm{AQ}$ ), dan kecerdasan spiritual (SQ) dalam lembaga pendidikan. Karena adanya paraktek-praktek dalam lembaga pendidikan yang hanya memprioritaskan kecerdasan akal belaka.

Penelitian ini mendukung pendapat Al-Ghazaly dan Nasih 'Ulwan yang menekankan urgensi pendidikan akhlak dan moralitas sejak anak usia dini,bahkan anjuran untuk mencari pasangan hidup yang kelak mampu mebangun keharmonisan rumah tangga sehingga melahirkan generasi yang berakhlak dan mandiri. Dalam penelitian ini penulis mendukung pendapat Darwis Hude dan Doni Koesoema yang menyatakan bahwa potensi anak bukan hanya terdapat pada kecerdsana akal, tapi ada kecerdasan lain seperti kecerdasan emosi, spiritual, dan ketahanan mental yang perlu dikembangkan secara seimbang. Penelitian ini juga mendukung teori karakternya Thomas Lickona yang menyatakan bahwa nilai moral dan karakter dapat diajarkan di sekolah. Hanya penulis tidak mendukung Lickona yang membatasi nilai moral hanya kepada sikap hormat dan tanggung jawab. Mendukung pendapat David Hume, tentang nilai yang menentang konsep Rasionalitas Decrates, yang membenarkan nilai-nilai dan moralitas 
berdasarkan akal belaka.

Temuan dalam penelitian berbeda pendapat dan sekaligus menyempurnakan konsep living value education (LVE) Diana Tillman, Rani Anggraeni Dewi, Trainer LVE Indonesia, dan ALIVE (Association for Living Values Education) Internasional pada pendidikan jenjang tingkat dasar. Konsep Tillman, LVE dan ALIVE mengklasifikasi nilai-nilai kunci pribadi dan sosial yang diajarkan sebagai nilai kehidupan. Nilai LVE yang mereka kembangkan menekankan pada nilai kebaikan dalam hidup bersama. Nilai- nilai tersebut adalah kedamaian, penghargaan, cinta, tanggungawab, kebahagiaan, kerjasama, kejujuran, kerendahan hati, toleransi, kesederhanaan, kebebasan, dan Persatuan. Berbeda pendapat juga dengan Decrates yang membatasi nilai-nilai berdasarkan rasionalitas, dan Thomas Aquinas yang yang menganggap nilai baik buruk bukan atas kehendak dirinya tapi hanya dari perilaku Tuhan.

\section{DAFTAR PUSTAKA}

Abdullah, Muhammad Husin, Mafâhim al-Islamiyah, diterjemahkan oleh Ramli dengan judul "Mafahim Islamiyah: Menajamkan Pemahaman Islam, Bangil: Al-Izzah, 2002.

Abdulsyani, Sosiologi Skematika, Teori, dan Terapan, Jakarta: Bumi Aksara, 1994.

Afifah, Nurul, "Problematika Pendidikan di Indonesia: Telah dari Aspek Pembelajaran", dalam Jurnal Elementary, Vol. I, Edisi 1, Januari 2015.

Agustina, Nora, Perkembangan Peserta Didik, Jakarta: Deepublish, 2018.

Ahmad, Abdul Aziz, Fiqih Cinta, Bandung: Pustaka Hidayah, 2009.

Ahlâm 'Atîq Mughly As-Sulamy, "Mafhum Al-Qiyam Wa Ahamiyatuhâ fî Al"Amaliyyah At-Tarbawiyyah Wa Tathbîqâtuhâ As-Sulukiyah min Mandhûr Islâmy”, dalam Jurnal Al-“Arabiyyah Li al-Ulum Wa Nasyr AlAbhâts, No. 02 Vol.III, Januari 2019.

Ahmad, Abu Husein bin Faris bin Zakaria, Mu'jam Maqayis Al-Lughoh, Beirut: Dar al-Fikr al-Ilmiyyah, 2011.

Ahmadi, Farid dan Hamidullah Ibda, Konsep dan Aplikasi Literasi Baru: di Era Revolusi Industri 4.0 dan Society 5.0, Semarang, Jawa Tengah: Pilar Nusantara, 2019.

Aizid, Rizem, Fiqh Keluarga Terlengkap, Yogyakarta: Laksana, 20018. Ali, Attabik dan Ahmad Zuhdi, Kamus Kontemporer Arab-Indonesia,155156

Jakarta: Yayasan Penyelenggara Penerjemahan al-Quran, 1973.

Ali, Mohammad, Pendidikan untuk Pembangunan Nasional: Menuju Bangsa Indonesia yang Mandiri dan Berdaya Saing Tinggi, Jakarta: Grasindo, 2009.

Ali, Muhamad Daud, Pendidikan Agama Islam, Jakarta: Raja Grafindo, 1998.

Al-Alusy Syihabuddin Mahmud bin Abdillah Al-Husainy, Ruh Al-Ma'any fi Tafsir Al-Qur'an Al-Adhim wa Al-Sab'i Al-Matsany, Vol II AlMaktabah Al-Syamilah.

Aly Ridha, Muhamad Rasyid bin, Tafsir Al-Manâr, Vol IV, Cairo: Al-

Hay'ah Al-Mishriyyah Al-Ammah Li-Alkitab, 1990 M.

Aly, Sirojuddin, Pemikiran politik Islam sejarah, praktik dan Gagasan, Jakarta: Rajagrafindo Persada, 2018.

Amin, A. Rifqi, Pengembangan Pendidikan Agama Islam: Reinterpretasi

Berbasis Interdisipliner, Yogyakarta: LKiS Pelangi Aksara, 2015. 
Amin, Maswardi M., Pendidikan Karakter Anak Bangsa, Yogyakarta: Calpulis, 2005.

Amin, Maswardi M., Pendidikan Karakter Anak Bangsa, Yogyakarta: Calplulis, 2015.

Amin, Samsul Munir, Menyiapkan Masa Depan Anak Secara Islami, Jakarta: Amazah, 2007.

Aminah, Mia Siti, Muslimah Career: Mencapai karir tertinggi di hadapan Allah, keluarga, dan pekerjaan, Yogyakarta: Pustaka Grhatama, 2010.

Amini, Ibrahim, Asupan Illahi Agar Tak Salah Mendidik Amanat-Nya, Jakarta: AL Huda, 2011.

Amrullah, Haji Abdul Malik Karim (HAMKA), Tafsir al-Azhar: diperkaya dengan pendekatan Sejarah, Sosiologi, Tasawuf, Ilmu Kalam, Sastra, dan Psikologi, Jakarta: Gema Insani, 1438 H /2016 M.

Al-Anshari, Syaikhul Islam Abi Yahya Zakaria Al-Anshari, Ghâyah al- wushûl syarh Lubb al-Ushûl, Al-Haramain: Ath-Thaba'ah Ats- Tsâniyah, 2016.

Antonio, Muhamad Syafi'I, et al, Sang pembelajar dan guru peradaban (Ensiklopedia Leadership and Manajemen Muhammad SAW. "The Super Leader Super Manager), Jakarta: Tazkia Publishing, 2011.

Anwar, AW. Evendi, Sentuhan Al-Qur'an untuk Kecerdasan Anak: Teknik dan Metode Membangkitkan Multi-Intelegensi dengan Stimulasi Al-Qur'an Sejak dalam Kandungan, Yogyakarta: Lkis Pelangi Aksara, 2016.

Anwar, M. Fuad, Landasan Bimbingan dan Konseling Islam, Yogyakarta: Budi Utama, 2019.

Anwar, Shabri Sheh, Teologi Pendidikan: Upaya Mencerdaskan Otak dan Qalbu, Riau: Indragiri TM, 2014

Aprillia, Ade dan Lidya Irawati, Diary Ibu Hamil: Berbagi Cerita menakjubkan selama kehamilan, Jakarta: Kawan Pustaka, 2014.

Arifin, M., Ilmu Pendidikan Islam, Jakarta: Bumi Aksara, 2001

Arikunto, Suharsimi, Prosedur Penelitian: Suatu Pendekatan Praktik, Jakarta: Rineka Cipta, 1993.

Arnold Toynbee, Sejarah Umat Manusia; Uraian Analitis, Kronologis, Naratif, dan Kompratif, Yogyakarta: Pustaka Pelajar, Cet.IV, 2007.

Al-Ashfahani, Al-Raghib, Mu'jam Mufradat Alfaadz Alquran, Baerut: Daar alFikr, 2004.

Asliman, Laurensius S, Penegakan Hukum dan Kesadaran Masyarakat, Yogyakarta: Deepublisher, 2015.

Asmani, Jamal Ma'mur, Buku panduan internalisasi pendidikan karakter di sekolah, Yogyakarta: Diva press, 2011.

Asmara, Toto, Spiritual Centered Leadership: Kepemimpinan Berbasis

Spiritual, Jakarta: Gema Insani Press, 2006.

Asy'arie, Musa, Manusia Pembentuk Kebudayaan dalam Alquran, Yogyakarta: LESFI, 1992.

Asyari, Suadi, Nalar Politik NU-Muhammadiyah: Overcrossing Java Sentris, Yogyakarta: LKiS, 2009.

Asyqar, Umar Sulaiman, Maqâshid Al-Mukallifîn: An-Niyyat fi Al-'ibadah, diterjemahkan oleh Faisal Saleh dengan judul Fiqih Niat dalam Ibadah, Jakarta: Gema Insani Press, 2005.

Atha'illah, Syekh Ahmad Ibnu, Al-Hikam diterjemahkan oleh M.Syamsil Hasan dan Aswadi, dengan judul menyelam ke Samudera Ma "rifat dan Hakekat", Surabaya: Penerbit Amelia, 2006 